multi-species models are now generally considered essential to scientific management, while the fact that stable populations can exist at more than one level and that spatial patchiness has much effect on the behaviour of populations serves to make our predictions from these models less secure. It is perhaps the case in population dynamics that the more we find out, the more we realise how much remains unknown. Many ecologists (following Elton) had been brought up to believe that increased complexity in a system begets increased stability, but May shows that in 'randomly-constructed' models increasing numbers of species are associated with increased dynamic fragility. However, as he points out, real communities are not constructed randomly, but consist of a number of sub-systems loosely coupled to each other. The nature of these inter-actions, for the most part, remains to be discovered.

Much remains for the population dynamicists to do; this book shows with what vigour and application they have up till now pursued their studies.

W. NIGEL BONNER

\title{
Arctic Summer, by Richard Vaughan. Nelson, £6.25.
}

This book chronicles a five week trip to the Varanger Peninsula in the summer of 1972 to photograph and record its birds. Lying beyond the limits of the spruce and almost wholly beyond the birch, considered as a tree, it is a true wilderness, except along the southern coastline where fishing villages and two small towns line the shore of the Varanger Fjord and numerous holiday huts dot the hillsides. The author made the acquaintance of several Norwegians living in the area who supplemented his own observations, and he has also studied the relevant Norwegian and English ornithological literature. From these sources he has been able to compile a systematic list of the birds of the peninsula, which, however, he says 'must be regarded as extremely provisional'. Somewhere along the line all mention of sea eagle has dropped out of this list, which is a pity as it is one of the species visitors would hope to see.

The main text describes the author's experience and is lavishly illustrated with black and white reproductions of his photographs, which achieve a consistently high standard of excellence that is remarkable when so much had to be done in so little time. Four pages of colour plates are particularly good, a male bluethroat being quite stunning.

G. DESS FORGES

\section{For Visitors to Indonesia}

Land Mammals of Indonesia (Inter.nasa, Jakarta) consists of fifty lively black and white drawings, each opposite a descriptive English text by Wendy Veevers-Carter. Some footprints are given (including tiger and rhino!) and a useful species list for each island in English, Latin and Indonesian.

Nature Conservation in Indonesia, by the same author and publisher, is a beautifully illustrated and informative guide to wildlife conservation and some of the country's superb reserves, including Udjung Kulon (last refuge of the Javan rhino) and Gunung Leuser. There are useful lists and maps and superb photographs by John Blower and Alain Compost superbly reproduced on a page ( $8 \mathrm{in} \times 10 \mathrm{in}$ ) large enough to do them justice.

\section{Bird Brief}

The latest New Naturalist volume is British Tits (Collins, $£ 8$ ), by Christopher Perrins, Director of the Edward Grey Institute for Field Ornithology at Oxford. So much field work has been done on our seven species of tits in recent years, particularly at Oxford, that it is high time this book was written - and an excellent and well illustrated one it is. Dr Perrins summarises and coordinates all this knowledge most ably, and at the same time shows how little we really know about the complicated lives of these attractive birds. This is a book for the ornithologist but with much to offer the birdwatcher. 